\title{
Article
}

\section{In the Shadow of Death: Jewish Affirmations of Life}

\author{
Paul Mendes-Flohr ${ }^{1,2}$
}

Citation: Mendes-Flohr, Paul. 2022. In the Shadow of Death: Jewish

Affirmations of Life. Religions 13: 26. https://doi.org/10.3390/rel13010026

Academic Editors: Achim Oberst and Susanne Claxton

Received: 24 November 2021

Accepted: 21 December 2021

Published: 28 December 2021

Publisher's Note: MDPI stays neutral with regard to jurisdictional claims in published maps and institutional affiliations.

Copyright: (C) 2021 by the author. Licensee MDPI, Basel, Switzerland. This article is an open access article distributed under the terms and conditions of the Creative Commons Attribution (CC BY) license (https:// creativecommons.org/licenses/by/ $4.0 /)$.
1 School of Divinity, University of Chicago, Chicago, IL 60637, USA; paulmendesflohr@gmail.com

2 Department of Jewish Thought, The Faculty of Humanities, Hebrew University of Jerusalem, Jerusalem 9190501, Israel

\begin{abstract}
The Book of Genesis reports that "On the sixth day of Creation "God saw everything that he had made, and behold, it was very good" (1:31). The very, so a Talmudic sage taught refers to "death". We are to share God's exultant affirmation of His work of creation as culminating in death. For death is intrinsic to the blessings of life. As Buber notes in the epigraph cited above, life is "unspeakably beautiful because death looks over our shoulder". The seeming paradox-an existential antinomy-inflected the vernacular Yiddish of my late father which was also that of Buber's youth "the one thing needful" (Luke 10:42); "love is strong as death" (Song of Songs; 8:6).
\end{abstract}

Keywords: apotropaic practices of East European Jewry; Martin Buber; Franz Rosenzweig; Joseph D. Soloveitchik; Hans Blumenberg

"The Script of life is so unspeakably beautiful to read because death looks over our shoulder" Martin Buber ${ }^{1}$

The Book of Genesis reports that "On the sixth day of Creation God saw everything that he had made, and behold, it was very good" (1:31). The very, so a Talmudic sage taught refers to "death." We are to share God's exultant affirmation of His work of creation as culminating in death. For death is intrinsic to the blessings of life. As Buber notes in the epigraph cited above, life is "unspeakably beautiful because death looks over our shoulder." The seeming paradox — an existential antinomy-inflected the vernacular Yiddish of my late father which was also that of Buber's youth.

My father's Yiddish was saturated with references to death. He would punctuate virtually every sentence with reverential homage to the Angel of Death, quickly followed by anxious implorations to the Evil Eye to keep menacing demons and the imminent threat of death at bay. Yet, at the same time, there was also a nigh-sober recognition-indeed, affirmation-that death is the ultimate signature of life. One would thus greet one on his or her birthday, with the blessing, "May you live to a hundred-and-twenty" (the mythic age of Moses at his death). ${ }^{2}$ May you be graced with a long and flourishing life until the ineluctable decree of death awaits us all ${ }^{3}$. The acknowledgment of death is integrated into the quotidian fabric of the life of Yiddish-speaking-Jewry.

One would embrace a newly born child by joyously proclaiming him or her as "meine Jahrzeit" - my memorial candle. ${ }^{4}$ (On the anniversary of a relative's death, one would light a memorial candle. It seemed that virtually every day there was a memorial candle flickering in the home of my youth.)

Buber concludes Daniel: Dialogues on Realization, a work of 1913 which is now largely overlooked although it sowed the seeds of the flowering of his philosophy of dialogue, with an extended meditation on death. In the voice of Daniel, he reviews several classical and well-established philosophical and theological strategies, as he later put it in Ich und $D u$, "born of mankind's craving to take the edge off the mystery of death" (Buber 1970). ${ }^{5}$

Acknowledging that he had entertained each of these views to avoid coming to terms with death and anesthetize its sting, Daniel explains that he found that he could not, for 
they failed to address the pressing, comprehend the incomprehensible reality of death, or the tragic passing of someone particularly dear to him. A companion, Lukas, told Daniel that having helplessly witnessed the drowning of a friend that he too could not reconcile himself to death:

The old mystery shuddered through me out of the present. Was life a ripening and death the entrance into a sphere of divine deed before which earthly life exists only as a simile? [ ... ] How could there be a There if it was not also here? How could I become death's if I had not already suffered it? [ . . ] There was not only in me a force that moved from the point of birth to the point of death or beyond; there was also a counterforce from death to birth, and each moment that I experienced as a living man had grown-out of the mixture of the two-they mixed with each other like man and wife and created by being. ${ }^{6}$

Lukas attests that in time he realized that Werden (becoming) and Vergehen (passing away) "did not alternate with each other". Rather, "they lay side by side in an endless embrace. [ ... ] It was foolish to wish to limit death to any particular moments of ceasing to be or of transformation; it was an ever-present might and the mother of being (Mutter des Seins)" 7 .

This feeling did not offer any "security", however; but it engendered an "unarmed trust in the infinite" as one embarks on the sea of life. In contrast to Hans Blumenberg's view of life's journey on the uncharted waters of the sea in which one never reaches a safe harbor, indeed, is ultimately destined to a shipwreck, ${ }^{8}$ Lukas embraces "the mystery of life's experience", and forges on "with forehead bent forward the demon of life sits at the rudder and with head thrown back the goddess of death sits at the prow". ${ }^{9}$ But the resulting tension unsettles the journey, buffeted by ever-intensifying puzzlement "what sort of a sea is it on which we travel? What sort of a sea has given birth to us, them and me?" To be sure, he concedes that he knows "that in some way I am myself this sea" (suggesting perhaps what Freud would cast as the psyche's conflicting instincts of Eros and Thanatos). But, with a sigh of existential regret, he adds that he cannot reach the solace of death "where I am it", the sea. The elixir of death is beyond time and the conditionality of the uncertain cadence of the ebb and flow of the sea of life. "Is what we call death, therefore, perhaps the way?" But "to think that is senseless; what life did not accomplish; death too will not produce. ${ }^{10}$

At this juncture in their conversation, Daniel intervenes and tells Lukas of his own experience. "Fleeing from the unformed world, I relied on my body and knew it as an island in the torrent of annihilations". ${ }^{11}$ He thus resolved to tear down "the eternal wall, the wall within me. In that hour, Lukas, the teaching came to me: the one thing that is needful. [Cf. Luke 10:42]. ${ }^{12}$ One must embrace "the tensions that he experiences in the storm" and not seek to flee them. One is not to retreat before "the fluctuating, raging world of division and contradiction". One should rather "renounce salvation than to exclude Satan's kingdom from it". One is to remain in the world, and not seek refuge behind or above it.

Indeed, Daniel assures Lukas, "there is in reality no $I$ except the $I$ of a tension. [ ... ] Can the ebb tide say I? Or the flood tide? But imagine the sea to have a spirit that comprehends in itself the unity of the ebb and flood: it could say I. ${ }^{13}$ The duality of life and death are to be experienced within oneself. "One half of me was life, the other had become death; in both, I found not states but powers, here the command of the surging blood, there the compulsion of death". ${ }^{14}$ And thus Daniel concludes:

We have spoken of death, my friend Lukas; we have all the time spoken of nothing else. You wish to know the holy sea, the unity that bears life and death in the right and left hand. You cannot know it otherwise than when you take upon yourself the tension of life and death and live through the life and death of the world as your life and death. The I of this tension will awaken in you-the unconditioned, the unity of life and death. ${ }^{15}$ 
The "awakened being" bears within herself the dialectic tension of time and the timeless, being conditioned and unconditioned, life and death. In death, one is no longer constrained by time. "This I is unconditioned. And this I is inextricably inserted in a human life". (Dieses Ich ist das Unbedingte, Und dieses 'Ich' ist eingestellt in einem Menschenleben.) To be sure, "human life cannot escape the conditioned. But the unconditioned stands ineffaceably in the heart of the world". ${ }^{16}$ This is, as Buber proclaims in Ich und Du, the "sublime melancholy" of the life of dialogue, which unfolds beyond the world of $I t$, conditioned by time and space. "Every Thou in the world is by its nature fated to become a thing; to continually re-enter the condition of things. [ . . ] The It is the eternal chrysalis, the Thou the eternal butterfly", but they are most often "an intricately entangled series of events that is tortuously dual"17 (oft ein in tiefer Zweifalt wirr vershlungnes Geschenen ${ }^{18}$ ).

Buber's future colleague Franz Rosenzweig would identify this "intricately entangled" duality of life and death as foundational. To the spiritual pulsations of Jewish religious life. While in the trenches of the Kaiser's army at the Balkan front, surrounded by lacerating bodies of fallen comrades in arms, he came to similar conclusions of Buber's Daniel:

Philosophy takes it upon itself to throw off the fear of things earthly, to rob death of its poisonous sting, and Hades of its pestilential breath. All that is mortal lives in this fear of death; every new birth augments the fear by one new reason, for it augments what is mortal. Without ceasing, the womb of the indefatigable earth gives birth to what is new, each bound to die, each awaiting the day of its journey into darkness with fear and trembling. But philosophy denies these fears of the earth. It bears us over the grave which yawns at our feet with every step. It lets the body be a prey to the abyss, but the free soul flutters away over it. Why should philosophy be concerned if the fear of death knows nothing of such a dichotomy between body and soul, if it roars Me! Me! Me!, if it wants nothing to do with relegating fear onto a mere 'body' ${ }^{19}$

Wedded to conceptual universals, philosophy cannot but fail to address the contingent reality of individual experience and "tear loose" death's "poisonous sting". 20 Trembling at the edge of the abyss, Rosenzweig thus concludes, one must condemn the "compassionate lie of philosophy" as, in fact, "cruel lying". ${ }^{21}$ For man-the singular, solitary, mortal individual_-"wants to remain, he wants—-to live", body and soul. ${ }^{22}$ "The terror of the earthly is to be taken from him only with the earthly itself. As long as he lives on earth, he will also remain in terror of the earthly. ${ }^{23}$

While still in the trenches, Rosenzweig resolved to probe the spiritual lineaments of Jewish religious practice as an affirmation of earthly existence in the shadow of death. Emerging from Armageddon with the conclusion of the World War, he assembled his notes and published less than a year later, Stern der Erlösung (Star of Redemption). In consonance with his rejection of conceptual constructs, philosophical and theological, he focuses on the liturgical life of the "synagogue" — the texts of its prayers as woven into its liturgical calendar of holidays, fasts of repentance, and proscribed recitation of biblical texts. At the heart of his phenomenological evocation of the traditional Jewish liturgical calendar, he focuses on the biblical book of the Song of Songs, which is recited communally during the morning service on the intermediate Sabbath of Passover. Under the influence of the Kabbalah, the custom arose, especially among the Hasidim and Sephardim, of reciting the Song of Songs on the eve of the Sabbath.

The inclusion of the Song of Songs in the Scripture, not to say in the liturgy on the face of it raised and continues to engender theological perplexity not only because of its unabashed erotic imagery but also since it does not once mention God. ${ }^{24}$ But it is precisely the 'sensuality' of The Song of Songs that renders it in Rosenzweig's view the most eloquent statement in the Hebrew Bible on the meaning of revelation, of the divine-human relation. Indeed, he refers to this love song as the "Kernbuch der Offenbarung". ${ }^{25}$ Yet God, as noted, is not once mentioned, nor even alluded to in this dialogue between a man and a woman, testifying to the physical delights and anguish of their mutual love. The Song's vivid 
imagery, expressing sexual affection and erotic desire would even be considered bold in our liberal culture.

In an exchange of lavish, indeed, hyperbolic praise of each other's physical features, the male lover exclaims, "How beautiful are thy feet in sandals, $\mathrm{O}^{\prime}$ prince's daughter! Thy rounded thighs are like jewels, the work of the hand of an artist. Thy navel is like a round goblet that never lacks wine; thy belly is like a heap of wheat set with lilies. Thy two breastlike two fawns, the twins of a gazelle" (7.2-4). And the female's response to her lover's ecstatic paean to her beauty and erotic appeal, is a laconic but exultant acknowledgment that his adoration and desire are reciprocal: "I am my beloved's, and his desire is toward me. Let's go forth into the field ..." (7.11).

Somehow these passionate love songs found their way into the Hebrew Bible. The debate among the rabbis responsible for establishing the canon regarding the appropriateness of their inclusion was brought to a close when Rabbi Akiva, venerated as Rosh ha-Hakhamim, the Chief of the Talmudic sages, declared "For all the ages are not worth the day on which the Song of Songs was given to Israel, for all the Ketuvim (Writings) are holy, but the Song of Songs is the Holy of Holies" (Mishnah Yadayim 3.5). There was a proviso, however. The Song of Songs was to be read as an allegory and its sexual imagery was ignored ${ }^{26}$ Hence, Jewish tradition understood the book as an allegorical testimony to the mutual love of God and the Children of Israel..$^{27}$ Refracted through this interpretative lens, the Song of Songs thus gained a firm footing in Israel's liturgy,

Christians also read the Song of Songs as an allegory. Starting with Origen, it has been read as bespeaking the relationship abiding between Christ and the Church, or between Christ and the individual believer. From the Renaissance on, there was a major hermeneutic shift, and the Song of Songs was increasingly read literally as a secular love song pur et simple. This trend, led by the Hebrew humanists Grotius and Clericus came to a head with Herder and Goethe, who expunged all remnants of allegorical reading of the book. ${ }^{28}$ As Rosenzweig observed:

Unfortunately, Herder and Goethe had at least preserved this much of the traditional conception: they regarded the Song of Songs only as a collection of love lyrics, thus leaving it its subjective, lyrical soul-revealing character. But thereafter the same road was followed further. Once the Song of Songs was understood as "purely human", the step from "purely human" to "purely worldly" was also possible. Thus, it was de-lyricized with a will. From every side, the effort was made to read dramatic action and epic content into it. [ ... ] Such comprehensive rearrangements or rather convulsions of the traditional text have been undertaken by biblical criticism on no other biblical book. [ . . ] The language of the revelation of the soul seemed somehow uncanny for the spirit of the century that recreated everything in its image, as objective and worldly. ${ }^{29}$

Read literally, the sensuality of the Song of Songs now preoccupied its commentators, and obliged them to ask rhetorically, "what strange error allowed these pages to slip into God's word? ${ }^{30}$ But Rosenzweig would regard the uncovering of the book's sensuality to be of great dialectical significance. Similarly, the questioning of the validity of reading it as an allegory brought into relief the meaning of the Song's putative analogy (Gleichnis) of human to divine love.

At this dialectical juncture of the modern interpretation of the Song of Songs, Rosenzweig notes, one is "confronted by the choice either to accept the 'purely human'. [the] purely sensual sense" of the book "or to acknowledge that the deeper meaning lodges here, precisely in the purely sensual sense, directly and "merely" in analogy ${ }^{31}$ Rosenzweig puts it paradoxically. The Song of Songs, because "it is indeed purely human, purely sensual'. it is "more than [an] analogy"32. The paradox is to be explained by Rosenzweig's understanding of anthropomorphic language that abounds in the Hebrew Scripture and, indeed, the religious imagination in general. For Rosenzweig, anthropomorphic imagery is not to be deemed, as many medieval philosophers and modern students of religion would 
say, an inevitable concession to human imagination; it is rather a theological necessity. The human and the divine do not inhabit two separate realities. There is thus, certainly with respect to love, an intrinsic or rather an ontological homology between human, dialogical love and divine love. Rosenzweig would, therefore, argue that love, human as well as divine, is sensual, and must be so. ${ }^{33}$

The recently published correspondence between Rosenzweig and Margrit Rosenstock, the wife of a close friend with whom he had a passionate affair, indicates that there was a strong autobiographical moment to this thesis. ${ }^{34}$ In fact, he wrote a draft of his commentary on the Song of Songs, while stretched out on his lover's bed waiting for her to appear for an appointed tryst. ${ }^{35}$ This perhaps explains the enigmatic prologue to the passages introducing his commentary. He opens the prologue with a citation from the Song of Songs, 'love is strong as death' (Stark wie der Tod ist Liebe. The Song of Songs, 8.6), and continues to ask, 'Strong in the same way as death? But against whom does love display its strength?' And he proceeds to answer his own question:

Against him whom it seizes. And love, of course, seizes both the lover as well as the beloved, but the beloved otherwise than the lover. It originates in the lover. The beloved is seized, her love is already a response to being seized: Anteros is the younger brother of Eros. [Anteros, one will recall is the god of passion, the god of mutual love and tenderness.] Initially, it is for the beloved that love is strong as death, even as nature has decreed that woman alone, not man, may die of love. What has been said of the twofold encounter of man and his self applies strictly and universally only to the male. As for woman, and precisely the most feminine woman above all, even Thanatos can approach her in the sweet guise of Eros. Her life is simpler than that of man by reason of this missing contradiction [between Eros and Thanatos]. Already in the tremors of love, her heart has become firm. It [her heart] no longer needs the tremor of death. A young woman can be ready for eternity as a man only becomes when his threshold is crossed by Thanatos. No man would die the death of an Alcestis [who volunteered to die for her husband, on Apollo's promise that her husband would never die if someone were found to die in his stead.] Once touched by Eros, a woman is what a man only becomes at the Faustian age of a hundred: ready for the final encounter-strong as death. ${ }^{36}$

Rosenzweig's oft-criticized sexist language is at least partially explained when one realizes that he wrote these words for his lover, Gritli as he affectionately called her. ${ }^{37}$ Further, he would undoubtedly concede, the roles of lover and beloved-of Eros and Anteros-can alternate. But his words, addressed to Gritli as a love letter, also had a theological message. Alluding to the closing sentence of Part Two of Goethe's Faust, he asserts, 'Like all earthy love, this is only an analogy'38 — an analogy that is also a homology. Human eros and divine eros are conterminous. For Rosenzweig human love is not a mere metaphor for divine revelation, nor does he, as one recent commentator observed, present "love as an alternative to death". ${ }^{39}$ Love is rather in his view a counterweightcomplementary necessity - to death, for, after all, it is not stronger than death; it is as strong as death. Being strong as death love neutralizes death's sting. Death remains, but when one is in the embrace of love, the existential anxieties attendant to our singularity, crowned as it is by our inexorable death, are cauterized and suspended.

Despite the edifying appeal of such a statement, it would be a mere apodictic assertion without an explication of the philosophical presuppositions of Rosenzweig's conception of revelation, or rather Offenbarungsglaube-his affirmation of divine revelation as a historical and existential fact. This faith was born of a long and difficult gestation. And if I may extend the metaphor, the birth of Rosenzweig's faith was facilitated by many midwives, representing various cultural and philosophical schools. In the end, the process focused on one overarching question: Can the concept of revelation address a reality that philosophy is inherently incapable of acknowledging? Although it took several years to crystallize, the answer was, at least as formulated, rather simple and straightforward. Since philosophy 
understands its mandate to illuminate necessary and universal truths, it excludes from its purview contingent or accidental phenomena, such as the genetic, cultural, and circumstantial details that determine the biography of each and every human being. By its very nature philosophy does not concern itself with the life story of an individual; the questions attendant to the existential singularity of an individual are beyond the ken and interest of philosophy. Focusing on universal necessary truths, philosophy is interested neither in the date of one's birth nor that of one's death, nor in the date of birth of one's children and their prospective, inevitable death-the contingent realities that engage one's deepest, most personal concerns. Or as Rosenzweig put it with disarming simplicity: Philosophy does address itself to a single living individual who has a first and last name. Yet one's being, one's existence is determined by the fact that each person has a first and last name. Viewed from this perspective, "The human being in the utter singularity of his individuality, in his being as determined by a first and last name (in seinem durch Vor- und Zuname festgelegten Sein), stepped out of the world which knew itself as the [rationally] conceivable world, out of the All of philosophy". ${ }^{40}$

Death is but the ultimate signature of one's singularity. One's death is experienced by anticipation, by the realization that one dies utterly alone, even if blessed with friends and family. ${ }^{41}$ It is in the light of this brute existential fact that we must live our lives as single, finite beings. And it is precisely in light of this existential fact that Rosenzweig concludes the Star of Redemption with the buoyant declaration "Into life" (ins Leben). Fully cognizant of our finitude, we are to journey into life. Philosophy may help survey the path, to chart the terrain and topography we are to encounter along the way, but, alas, it cannot relieve of us the existential anxieties engendered by our singularity. Since time immemorial philosophy, east, and west, has recommended that we transcend these concerns by splitting ourselves into two, a body and a soul; one should focus on the soul as the true center of one's being, one's ontos, which bears the imprint and thus promises of eternity, and our transitory bodies that indeed are destined to perish. Modern, post-Enlightenment philosophers have offered a twist to this division by suggesting that one transcend one's finite self by identifying with humanity. Rosenzweig regarded Kant's formula as most representative of this view. One gains a glimpse of immortality, to be sure, as but a postulate of practical reason, when one transcends oneself-ignores the promptings of one's own inclinations and concerns-and heeds the categorical imperative and therefore acts on behalf of rational humanity and the universal ideal of an ethical community. Within these equations, ancient and modern, the particularities of the em-bodied self are left out, are abstracted. With reference to the Kantian discourse, Rosenzweig speaks of the meta-ethical self, the self not comprehended by the universal compass of the practical reason. ${ }^{42}$ But the self invariably protests. Enjoining an ontological distinction between the body and soul, expressed with various terms, philosophy denies 'the fears of the earth' 43 .

In contrast to philosophy, the Offenbarungsglaube that determines the existential ground of biblical faith cannot concede a division of body and soul, of a self, abstracted from the particularities of one's lived life. Divine revelation, Rosenzweig maintains, addresses one's earthly anxieties, one's meta-ethical self-enmeshed in the existential, often petty, and banal, but nonetheless ever-pressing realities of one's utterly singular, embodied life. In revelation, God addresses each and every one of us by our first and last name, acknowledges the particularities of our finitude, our finite, embodied existence, in particular, distinctive bodies, bracketed by particular, distinctive biographies. Addressing the singularity of a particular existence, revelation must perforce be sensuous. It does not address the universal ontos one happens to inhabit or share in, but it addresses one with a first and last name, as one who has a particular date of birth and as yet undetermined day of death, it addresses one who dwells in a particular body, and whose heart palpitates with distinctive earthly fears and hopes. In this respect, revelation is love, and as such is analogous and homologous with mundane love, of the love of one human being for another. We love one another as embodied in our particularities, and when that love is erotic it includes the shape of the other's face, the aroma of the other's skin, the quality of her or his voice. Love is perforce sensuous-and 
ergo as strong as death. Love does not conquer death or eliminate it. But while death is "the ineradicable stamp of [our] creatureliness," ${ }^{44}$ it also marks the dénouement of life; in contrast to other creatures, we humans are conscious of the inevitability of our death. As the Psalmist notes, we walk in the shadow of death, of our own and that of others who are dear to us. The dark shadows of death denote the anticipated "has been" or past perfect of human existence.

In contrast to death, love is utterly in the present. Hence, "Love which knows solely the present, which lives on the present, pines for the present-it challenges death" ${ }^{\prime 45}$-not death in general as an abstract concept but the death that is the supreme emblem of our singularity and that will consummate our existential finitude. Hence, Rosenzweig concludes, "the keystone of the somber arch of creation [that is, our death, the pinnacle of our singularity] becomes the cornerstone of the bright house of revelation. For the soul, revelation means the experience of a present (Erlebnis einer Gegenwart)" ${ }^{\prime \prime 6}$. So it is for divine and human love.

Love lives in the present tense, death points to the past perfect. Love signals an undivided attentiveness to the present and the presence of an Other, in love one beholds the Other un-deflected by considerations of time, of past or future; in love, one draws the Other out of the undifferentiated multitude of humanity and celebrates the Other's particularity. Love is perforce sensuous and thus neutralizes the existential sting of our finitude. That is why love-human and divine-is, indeed, the crown of creation. Thus, Rosenzweig comments:

The created death of the creature portends the revelation of a life which is above the creaturely level. For each created thing, death is the very consummator of its entire materiality. It removes creation imperceptibly into the past, and thus turns it into the tacit, permanent prediction of the miracle of its renewal [through love]. That is why, on the sixth day, it was not said that it was "good", but rather "behold, very good!" "Very", so our sages teach, "very"- that is death. ${ }^{47}$

Echoing the 'very good' of creation, the Song of Songs exclaims, 'Love is strong as death'. Love does not conquer death, but is strong as death, enabling us to affirm life and "to walk humbly with thy God":

noting more is demanded there than a wholly present trust. But trust is a big word. It is the seed whence grow faith, hope, and love, and the fruit which ripens out of them. It is the very simplest and just for that the most difficult. It dares at every moment to say Truly to the truth. To walk humbly with thy God-the words are written over the gate, the gate which leads out of the miraculous light of the divine sanctuary in which no man can remain alive. Whither, then, do the wings of the gate open? Thou knowest it not? INTO LIFE ${ }^{48}$

Funding: This research received no external funding.

Institutional Review Board Statement: Not applicable.

Informed Consent Statement: Not applicable.

Conflicts of Interest: The author declares no conflict of interest.

\section{Notes}

(Buber 2018, p. 91). Cf. "Die Schrift des Lebens ist so unsäglich schön zu lesen, weil uns der Tod über die Schultern schaut". (Buber 2001, p. 210).

2 Rabbi Meir, 200 AC. Midrash Genesis Rabbah, ed., Chanoch Theodor Albeck, parashah 9 (Hebrew).

3 My father was born in Galicia, the Eastern province of the Austrian-Hungarian Empire. Since the age of three, Buber was raised in the home of his grandparents in the capital of Galicia, Lemberg (Lvov).

4 Apothropic gestures to defer the decree of death abounded in the folk-culture of Galician Jewry. A premature baby, my grandfather was proleptically called since his birth Zeide, grandpa. A very ill-child would be given the sobriquet, Alter, denoting a senior citizen.

5 (Buber 1970, p. 56) and the extensive bibliography there. 
Buber, Daniel. Dialogues on Realization, pp. 130-31. Daniel. Gespräche über die Verwirklichung, 236.

Daniel. Dialogues on Realization, p. 131. Daniel. Gespräche über die Verwirklichung, 236.

(Blumenberg 1979) and the extensive bibliography there.

Daniel. Dialogues on Realization, p. 131.

Ibid.

Ibid., p. 134.

Ibid., p. 135. Cf. "But one thing is needful: and Mary hath chosen that good part, which shall not be taken away from her". Luke 10:42 (King James translation). This somewhat gnomic declaration of Jesus is generally understood as indicating that while assuring Mary that she may rejoice in her material blessings, he sought to remind her-and us—that there is but one thing which endows life with spiritual blessings, namely, devotion to God. Buber's Daniel came to realize that "the one thing needful" is to embrace life as spiritual journey, albeit often buffeted, as Shakespeare's Hamlet bemoaned, by "slings and arrows", as crowned by the spiritual blessing of death.

Ibid., p. 142.

Ibid., p. $134 \mathrm{f}$.

Ibid., p. 144.

Ibid., p. 143.

I and Thou, 69.

Ich und $\mathrm{Du}, 18$.

(Rosenzweig 1970, p. 3) and the extensive bibliography there.

Ibid., p. 4f.

Ibid., p. 5.

Ibid., p. 3.

Ibid., p. 4.

One hermeneutic strategy to explain the eroticism of the Song of Songs is presented in Pope Benedict XVI's inaugural encyclical, Deus Caritas Est (God is Love) of January 2006. The Holy See notes that the Song has two Hebrew words for love, dodim, 'a plural form suggesting a love that is still insecure, indeterminate and searching'. This love he identifies with human eros, which 'comes to be replaced by the word $a h a b a^{\prime}$. or in Christian parlance, agape. As 'the typical expression of biblical notion of love'. agape is to be contrasted 'with an indeterminate, "searching" love'. Agape 'expresses the experience of a love which involves a real discovery of the other, moving beyond the selfish character that prevailed earlier' with eros. 'Love now becomes concern and care for the other. No longer is it a self-seeking, a sinking in the intoxication of happiness; rather it seeks the good of the beloved: it becomes renunciation, and it is ready, and willing, for sacrifice'. In a word, according to this reading, the Song of Songs projects a trajectory from 'erotic love (eros)' to a 'self-donating love (agape)'. which Pope Benedict XVI characterizes as a 'path of ascent and purification'. In a word, according to this reading of the Song of Songs, the erotic must be overcome and transcended. Rosenzweig would demur. For him, as we shall argue, eros is the existential grammar of both human and divine love.

(Rosenzweig 1930, p. 147) and the extensive bibliography there.

Thus, the reference to the beloved's breasts were to be read as a simile for the "two tablets of Torah".

(Gottlieb 1992, pp. 1-17). Cf. "Allegorical explanations are rare in Jewish exegesis, except for this [the Song of Songs]". Ibid., p. 2.

For a detailed and perceptive review of the history of Christian interpretations of the Song of Songs, especially as pertinent to Rosenzweig's understanding of that history, see (Moyn 2005a, pp. 194-212).

The Star of Redemption, 200.

Ibid., p. 199.

Ibid.

Ibid., pp. 199, 201.

(Rosenzweig 1984, pp. 731-46; Galli 1993, pp. 219-43) and the extensive bibliography there.

See Rosenzweig's letter on Margrit Rosenstock, 15 November 1918: 'Liebe, II 2 [that is, the section of The Star of Redemption dealing with the Song of Songs] ist so schön. Ich freue mich auf die Stunden im grünen Zimmer [Margrit's bedroom], wo ich dir Hauptstücke vorlesen werde. Diesmal zuerst nur mit dir allein. [ . . . ] Eigentlich kennst du es freilich schon, es steht wohl ebensoviel von dir drin wie von mir. (Rosenzweig 2002, p. 190).

See (Casper 1986, pp. 65-71) and the extensive bibliography there.

Star of Redemption, 156 .

Cf. 'Das Buch II 2 [ ... ] gehört dir. [ . . . ] Es ist nicht “Dir" aber-dein. Dein-wie ich'. Rosenzweig to Margrit Rosenstock, 2 November 1918. Grili-Briefe., p. 177.

Star of Redemption, 156. 
(Moyn 2005b, p. 146) (italics in original).

Stern der Erlösung, vol. 1, p. 16; The Star of Redemption, p. 10 (translation emended).

The esteemed Talmudic scholar Joseph B. Soloveitchik (1903-1993) expressed remarkably similar observations: “I am lonely. Let me emphasize, however, that by stating 'I am lonely' I do not intend to convey to you the impression that I am alone. I, thank God, do enjoy love and friendship of many. I meet people, talk, preach, argue, reason. And yet, companionship and friendship do not alleviate the passional experience of loneliness which trails me constantly. I am lonely because I feel [as a man of faith] rejected by everyone, not exclusively by intimate friends, and the words of the psalmist, 'My father and mother have forsaken me' ring quite often in my ears as the plaintive cooing of the turtledove. It is a strange, alas, absurd experience of engendering sharp, enervating pain as well a stimulating cathartic feeling. [..] I feel invigorated because the very experience of loneliness presses everything in me to the service of God. In my 'desolate howling solitude'. I experience a growing awareness that, to paraphrase Plotinus's apothegm about prayer, this service to which I, a lonely and solitary individual am committed to is wanted and gracefully accepted by God in His transcendental loneliness and numinous solitude". (Soloveitchik 2006, pp. 3-4). Star of Redemption, 10f, pp. 63-82.

Ibid., p. 3.

Ibid., p. 156.

Ibid., p. $156 \mathrm{f}$.

Ibid., p. 157; Der Stern der Erlösung, vol. 2, p. 89.

Ibid., p. 155.

Ibid., p. 424.

\section{References}

Blumenberg, Hans. 1979. Schiffbruch Mit Zuschauer: Paradigma Einer Daseinsmetapher. Berlin: Suhrkamp.

Buber, Martin. 1970. Walter Kaufmann. New York: Charles Scribner's Sons.

Buber, Martin. 2001. Daniel. Gespräche von der Verwirklichung (1913). In Martin-Buber-Werkausgabe, hrsg. P. Mendes-Flohr, Peter Schäfer, B. 1: Frühe kulturkritische und philosophische Schriften 1891-1924, Bearbeitet, eingeleitet und kommentiert von Martin Treml. Güterlohr: Güterloher Verlagshaus.

Buber, Martin. 2018. Daniel. Dialogues on Realization. In Maurice Friedman, New Foreword by Paul Mendes-Flohr. Syracuse: Syracuse University Press.

Casper, Bernard. 1986. Von Einheit und Ewigkeit. Ein Gespräch zwischen Leib und Seele: Ein unveröffentlichter Text Franz Rosenzweigs. Bulletin des Leo-Baecks-Instituts 74: 65-71.

Galli, Barbara. 1993. Rosenzweig Speaking of Meetings and Monotheism in Biblical Anthropomorphisms. The Journal of Jewish Thought and Philosophy 2: 219-43. [CrossRef]

Gottlieb, Isaac. 1992. The Jewish Allegory of Love: Change and Constancy. The Journal of Jewish Thought and Philosophy 2: 1-17. [CrossRef]

Moyn, Samuel. 2005a. Divine and Human Love. Franz Rosenzweig's History of the Song of Songs. Jewish Studies Quarterly 12: 194-212. [CrossRef]

Moyn, Samuel. 2005b. Origins of the Other. Emmanuel Levinas between Revelation and Ethics. Ithaca and New York: Cornell University Press, p. 146.

Rosenzweig, Franz. 1930. Der Stern der Erlösung, 2nd ed. Berlin: Schocken Verlag, vol. 2.

Rosenzweig, Franz. 1970. The Star of Redemption. Translated by William W. Hallo. New York: Holt, Reinhart and Winston.

Rosenzweig, Franz. 1984. Zur Encyclopedia Judaica. In Rosenzweig, Der Mensch und sein Werk. Gesammelte Schriften, vol. 3: Zweistromland. Edited by Kleinere Schriften zu Glauben und Denken Reinhold and Ann Marie Mayer. Dordrecht: Martinus Nijhoff Publishers, pp. 731-46.

Rosenzweig, Franz. 2002. Rosenzweig, Die 'Grittli'-Briefe: Briefe an Margrit Rosenstock-Huessy. Edited by Inken Ruhle and Reinhard Mayer. Tübingen: Bilam.

Soloveitchik, Joseph B. 2006. The Lonely Man of Faith. New York: Doubleday. 